\title{
Friction and Wear Properties of Copper/Carbon/Rice Bran Ceramics Composite under Water-Lubricated Condition
}

\author{
Kei Shibata*, Takeshi Yamaguchi and Kazuo Hokkirigawa \\ Graduate School of Engineering, Tohoku University \\ 6-6-01 Aramaki Aza-Aoba, Aoba-ku, Sendai, Miyagi 980-8579, Japan \\ *Corresponding author: shibata@gdl.mech.tohoku.ac.jp
}

( Manuscript received 29 October 2010; accepted 28 December 2010; published 31 Junuary 2011 )

\begin{abstract}
In this paper, friction and wear properties of a copper/carbon/rice bran ceramics $(\mathrm{Cu} / \mathrm{C} / \mathrm{RBC})$ composite under water-lubricated conditions were investigated experimentally. The mass fractions of copper, carbon and the RB ceramics particulates were 60,35 and 5 mass $\%$, respectively. The mean diameter of the RB ceramics particulate was $4.9 \mu \mathrm{m}$. Friction tests were conducted with a pin-on-disk friction apparatus under water-lubricated conditions. The $\mathrm{Cu} / \mathrm{C} / \mathrm{RBC}$ composite and a copper/carbon $(\mathrm{Cu} / \mathrm{C})$ composite were used as disk specimens. The $\mathrm{Cu} / \mathrm{C}$ composite is a conventional pantograph slider material in Japan. A copper alloy was used as a pin specimen, which was used to simulate a contact wire. The friction coefficients for the $\mathrm{Cu} / \mathrm{C} / \mathrm{RBC}$ composite were lower and more stable than those for the $\mathrm{Cu} / \mathrm{C}$ composite. The $\mathrm{Cu} / \mathrm{C} / \mathrm{RBC}$ composite showed superior friction and wear properties such as $70.0 \%$ reduction in friction coefficient, $86.1 \%$ reduction in the specific wear rate of the composite disk and $99.1 \%$ reduction in that of the copper-alloy pin compared with the $\mathrm{Cu} / \mathrm{C}$ composite.
\end{abstract}

Keywords: copper/carbon/rice bran composite, friction, wear, water-lubricated condition, pantograph slider

\section{Introduction}

Recently, a reduction of maintenance costs in railways has been required. A slider in a pantograph -a current collector system in an electric train- is replaced at regular intervals due to wear. Improving the wear resistance of the pantograph slider can reduce costs by decreasing replacement frequency. A composite material of copper and carbon $(\mathrm{Cu} / \mathrm{C}$ composite $)-a$ metalized carbon slider ${ }^{1}$ - has been conventionally used as a pantograph slider of local trains. However, further improvement of its wear resistance is required.

In order to improve wear resistance of a pantograph slider, new composite materials were prepared by sintering copper, carbon and rice bran $(\mathrm{RB})$ ceramics particulates. RB ceramics are hard porous carbon materials that are prepared by carbonizing a mixture of rice bran and phenol resin, which show low friction and high wear resistance under dry conditions. The pantograph slider slides against a contact wire with electric current. When the slider is detached from the contact wire, arc-discharge sometimes occurs, which results in a severe wear.

In previous studies ${ }^{2,3)}$, the friction and wear properties of copper/carbon/rice bran ceramics $(\mathrm{Cu} / \mathrm{C} / \mathrm{RBC})$ composites were investigated under (i) dry conditions without electric current ${ }^{2)}$, (ii) dry conditions with electric current but without arc-discharge ${ }^{3)}$ and (iii) dry conditions accompanied with arc-discharge $e^{3)}$. These studies indicated that the $\mathrm{Cu} / \mathrm{C} / \mathrm{RBC}$ composite showed superior tribological properties to the $\mathrm{Cu} / \mathrm{C}$ composite under dry conditions without electric current and dry conditions with electric current without arc-discharge. However, the wear resistances of the $\mathrm{Cu} / \mathrm{C}$ and $\mathrm{Cu} / \mathrm{C} / \mathrm{RBC}$ composites were the same under dry conditions accompanied with arc-discharge, which suggested that the addition of RB ceramics particulate provides no influence on the wear resistance to $\operatorname{arc-discharge~}^{3)}$.

The pantograph slider is used under various environmental conditions such as dry, wet and snow. It would be essential to investigate the effects of environmental conditions on friction and wear of the $\mathrm{Cu} / \mathrm{C} / \mathrm{RBC}$ composites in consideration of its practical application to the pantograph slider. The actual contact wire is extremely longer than the pantograph slider. Therefore, friction and wear tests modeling perfectly the actual sliding contact between the contact wire and the disk specimen would be difficult.

On the basis of the background described above, the purpose of this study is to obtain the fundamental friction and wear properties between the $\mathrm{Cu} / \mathrm{C} / \mathrm{RBC}$ 
Table 1 Composition ratios and mechanical, electrical properties of each composite

\begin{tabular}{c|c|c}
\hline Composite materials & $\mathrm{Cu} / \mathrm{C} / \mathrm{RBC}$ & $\mathrm{Cu} / \mathrm{C}$ \\
\hline Mean diameter of RBC particulate $d_{\mathrm{m}}, \mu \mathrm{m}$ & 4.9 & - \\
$\mathrm{RBC} \alpha$, mass $\%$ & 5 & 0 \\
Mass fraction $\quad$ Carbon $\beta$, mass $\%$ & 35 & 40 \\
Copper $\gamma$, mass $\%$ & 60 & 60 \\
\hline Density $\rho, \mathrm{Mg} / \mathrm{m}^{3}$ & 3.6 & 3.5 \\
Electric resistivity $R, \mu \Omega \cdot \mathrm{m}$ & 2.0 & 1.2 \\
Bending strength $\sigma_{\mathrm{B}}, \mathrm{MPa}$ & 106 & 108 \\
Charpy impact value $E_{\mathrm{c}}, \mathrm{kJ} / \mathrm{m}^{2}$ & 3.6 & 3.7 \\
\hline
\end{tabular}

composite and the copper alloy under water-lubricated conditions without electric current by laboratory tests using the pin-on-disk friction test apparatus.

\section{Experimental}

\subsection{Sample preparation}

The RB ceramics particulate was prepared by carbonizing a mixture of defatted rice bran and phenol resin at 900 degrees $C$ in an atmosphere of nitrogen ${ }^{4)}$. Compounds of copper, carbon and the RB ceramics particulates were formed into a block shape. The mass fractions of their particulates were 60,35 and 5 mass $\%$, respectively. The mean diameter of RB ceramics particulate was $4.9 \mu \mathrm{m}$. The fraction and diameter condition was based on the previous study ${ }^{2)}$. Pitch and coke constituted the carbon particulate. The formed block was sintered in an inert gas below 1000 degrees C. The $\mathrm{Cu} / \mathrm{C}$ composite, the conventional pantograph slider material, was also prepared as a comparison. The carbon in each composite was a soft amorphous carbon. Each block was cut into a plate shape $(50 \mathrm{~mm} \times 50 \mathrm{~mm}$ $\times 10 \mathrm{~mm}$ ). Then their test surfaces were finished by grinding. The surface roughness, $R_{\mathrm{a}}$, of the $\mathrm{Cu} / \mathrm{C} / \mathrm{RBC}$ and the $\mathrm{Cu} / \mathrm{C}$ composites was 2.3 and $2.4 \mu \mathrm{m}$, respectively. Table 1 shows the composition ratios and the mechanical, electrical properties of each composite. $\mathrm{The} \mathrm{Cu} / \mathrm{C} / \mathrm{RBC}$ composite satisfied the requirements for a pantograph slider material of the bending strength greater than $70 \mathrm{MPa}$ and the electric resistivity less than $3 \mu \Omega \cdot \mathrm{m}$. Fig. 1 shows SEM images and elemental analysis of the testing surfaces of each composite. The bright areas in the SEM images represent copper areas.

\subsection{Experimental procedure}

Figure 2 shows the pin-on-disk friction test apparatus. Disk specimens were the $\mathrm{Cu} / \mathrm{C} / \mathrm{RBC}$ and the $\mathrm{Cu} / \mathrm{C}$ composite. A pin specimen $(\varphi=2 \mathrm{~mm}$ with the length of $13.5 \mathrm{~mm})$, simulating a contact wire, was copper alloy $(\mathrm{Cu}: 99.7 \pm 0.05 \%, \mathrm{Sn}: 0.3 \pm 0.05 \%)$. The surface roughness, $R_{\mathrm{a}}$, of the pin specimen was $0.4 \mu \mathrm{m}$. The normal load, $W$, was $9.8 \mathrm{~N}$ (the corresponding apparent contact pressure, $P$, was $3.12 \mathrm{MPa}$ ). The sliding velocity, $v$, was $3 \mathrm{~m} / \mathrm{s}$ (the rotation speed was $1910 \mathrm{rpm}$, the rotation radius was $15 \mathrm{~mm}$ ). Thus, the $P v$

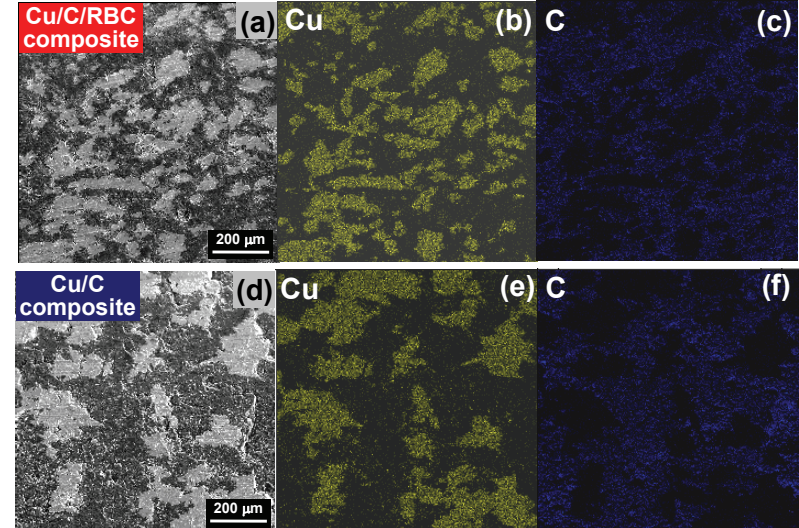

Fig. 1 SEM images and elemental analysis of surfaces of each composite: (a) SEM image of $\mathrm{Cu} / \mathrm{C} / \mathrm{RBC}$ composite; (b) mapping of $\mathrm{Cu}$ in (a); (c) mapping of $\mathrm{C}$ in (a); (d) SEM image of $\mathrm{Cu} / \mathrm{C}$ composite; (e) mapping of $\mathrm{Cu}$ in (d); and (f) mapping of $\mathrm{C}$ in (d)

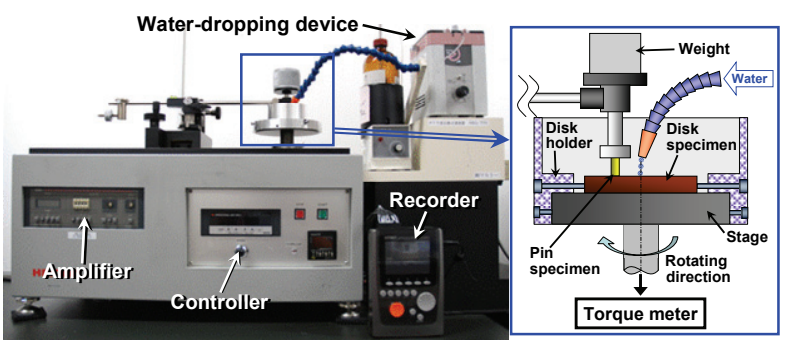

Fig. 2 Schematic diagram of pin-on-disk friction apparatus

value was $9.36 \mathrm{MPa} \cdot \mathrm{m} / \mathrm{s}$, which was equivalent to the actual working conditions of the pantograph slider. Droplets of purified water were supplied in the vicinity of the contact area between the pin and the disk specimens. The dropping rate of the purified water was $63 \mathrm{~mm}^{3} / \mathrm{s}$. The number of repeat passages was $5 \times$ $10^{4}$ cycles. A friction coefficient was calculated based on a friction force measured with a torque meter coupled with the axis of the rotational stage. A specific wear rate of the disk specimen was calculated based on a wear volume measured with a profilometer and that of the pin specimen was calculated from a mass loss measured with an electronic balance.

\section{Results and discussion}

Figure 3 shows the variation of the friction coefficients for the $\mathrm{Cu} / \mathrm{C} / \mathrm{RBC}$ and the $\mathrm{Cu} / \mathrm{C}$ composites with the number of repeat passages. The friction coefficients for the $\mathrm{Cu} / \mathrm{C}$ composite had high values around 0.4 at the initial stage of friction. At $1.2 \times$ $10^{4}$ cycles, severe vibration occurred in the apparatus. Therefore this friction test was terminated. For the $\mathrm{Cu} / \mathrm{C} / \mathrm{RBC}$ composite, on the other hand, the friction coefficients decreased at the initial stage of friction and then kept low values around 0.12 . The $\mathrm{Cu} / \mathrm{C} / \mathrm{RBC}$ composite showed $70.0 \%$ reduction in the friction coefficient compared with the $\mathrm{Cu} / \mathrm{C}$ composite. 
Figure 4 shows the surface profile on each composite disk after the friction test. The wear depth of the $\mathrm{Cu} / \mathrm{C} / \mathrm{RBC}$ composite was obviously shallower than that of the $\mathrm{Cu} / \mathrm{C}$ composite. The worn surface of the $\mathrm{Cu} / \mathrm{C} / \mathrm{RBC}$ composite was $R_{\mathrm{a}}$ of $1.0 \mu \mathrm{m}$ and $R_{\mathrm{y}}$ of $8.0 \mu \mathrm{m}$. The worn surface of the $\mathrm{Cu} / \mathrm{C}$ composite was $R_{\mathrm{a}}$ of $2.2 \mu \mathrm{m}$ and $R_{\mathrm{y}}$ of $20.4 \mu \mathrm{m}$. Thus, the worn surface of the $\mathrm{Cu} / \mathrm{C} / \mathrm{RBC}$ composite was smoother than that of the $\mathrm{Cu} / \mathrm{C}$ composite.

Figure 5 shows the specific wear rates of each composite disk. The specific wear rate of the $\mathrm{Cu} / \mathrm{C} / \mathrm{RBC}$ composite was lower than that of the $\mathrm{Cu} / \mathrm{C}$ composite. That of the $\mathrm{Cu} / \mathrm{C} / \mathrm{RBC}$ composite was $8.5 \times$ $10^{-8} \mathrm{~mm}^{2} / \mathrm{N}$. The reduction of the specific wear rate of the $\mathrm{Cu} / \mathrm{C} / \mathrm{RBC}$ composite was $86.1 \%$ compared with the $\mathrm{Cu} / \mathrm{C}$ composite.

Figure 6 shows the specific wear rates of the copper-alloy pins which slid against each composite disk. The specific wear rate of the pin which slid against the $\mathrm{Cu} / \mathrm{C} / \mathrm{RBC}$ composite was extremely lower than that which slid against the $\mathrm{Cu} / \mathrm{C}$ composite. That of the pin which slid against the $\mathrm{Cu} / \mathrm{C} / \mathrm{RBC}$ composite was $1.0 \times$ $10^{-8} \mathrm{~mm}^{2} / \mathrm{N}$. The reduction in the specific wear rate of the pin which slid against the $\mathrm{Cu} / \mathrm{C} / \mathrm{RBC}$ composite was $99.1 \%$ compared with that against the $\mathrm{Cu} / \mathrm{C}$ composite. According to Figs. 5 and 6 , the $\mathrm{Cu} / \mathrm{C} / \mathrm{RBC}$ composite showed not only high wear resistance but also extremely low aggression to the mating material

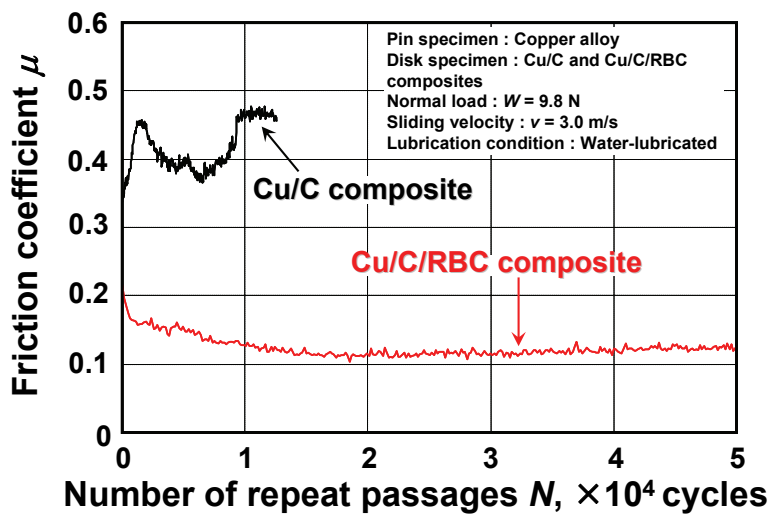

Fig. 3 Variation of friction coefficients for each composite with number of repeat passages

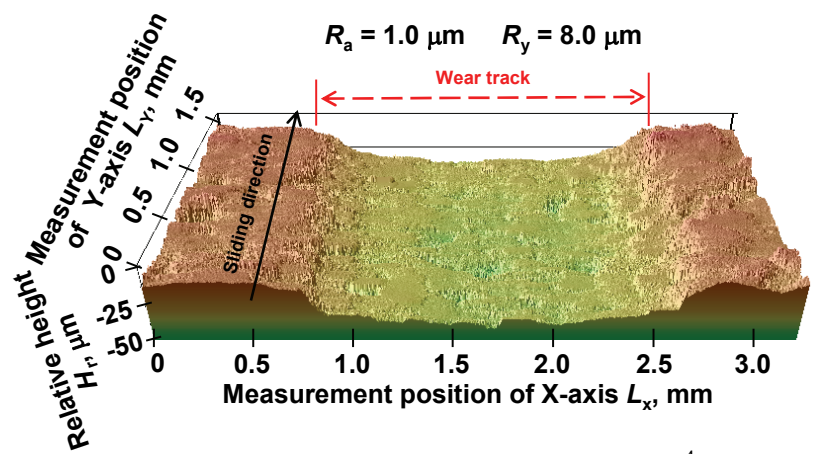

(a) $\mathrm{Cu} / \mathrm{C} / \mathrm{RBC}$ composite disk at $5.0 \times 10^{4}$ cycles compared with the $\mathrm{Cu} / \mathrm{C}$ composite.

Figure 7 shows SEM images of typical appearances of the worn surfaces on each composite disk after testing. It was clearly observed in Fig. 7 that not only copper parts but also carbon/RB ceramics parts in the $\mathrm{Cu} / \mathrm{C} / \mathrm{RBC}$ composite were smooth. In the $\mathrm{Cu} / \mathrm{C}$ composite, on the other hand, both copper and carbon parts were rough. Additionally, deep scratches were observed on the copper part in the $\mathrm{Cu} / \mathrm{C}$ composite. Moreover, the copper area on the worn surface of the $\mathrm{Cu} / \mathrm{C}$ composite appeared larger than that of the $\mathrm{Cu} / \mathrm{C} / \mathrm{RBC}$ composite possibly due to plastic flows.

Figure 8 shows SEM images of the worn surfaces of the copper-alloy pins after testing. In Fig. 8, plastic flows and a large number of scratches were observed on the worn surface which slid against the $\mathrm{Cu} / \mathrm{C}$ composite. On the worn surface which slid against the $\mathrm{Cu} / \mathrm{C} / \mathrm{RBC}$ composite, in contrast, the plastic flows were extremely small in amount, and the worn surface was also smooth.

On the basis of these observations, it was considered for the $\mathrm{Cu} / \mathrm{C}$ composite that brittle fractures of the carbon parts resulted in a number of copper (of the disk)/copper (of the pin) contacts. High adhesion occurred in the copper/copper contacts allowing large plastic flows. On the contrary, such plastic flow of copper areas occurred less for the $\mathrm{Cu} / \mathrm{C} / \mathrm{RBC}$ composite, possibly due to an increase of the wear resistance of the carbon parts by adding the RB ceramics particulate. Furthermore, the fine wear debris of the soft amorphous carbon and the hard amorphous carbon (RB ceramics) on the sliding surface would generate a good lubrication with water. Thus the $\mathrm{Cu} / \mathrm{C} / \mathrm{RBC}$ composite kept low friction coefficients around 0.12 .

The specific wear rate of the $\mathrm{Cu} / \mathrm{C} / \mathrm{RBC}$ composite under dry conditions without electric current was $6.3 \times$ $10^{-9} \mathrm{~mm}^{2} / \mathrm{N}^{2)}$. This value was lower than that under water-lubricated conditions obtained in this study. Thus, the $\mathrm{Cu} / \mathrm{C} / \mathrm{RBC}$ composite showed a poorer wet wear resistance. RB ceramics include the inorganic components of $\mathrm{K}, \mathrm{Mg}, \mathrm{P}$ and $\mathrm{Na}$. These components produce deliquescent components like $\mathrm{K}_{2} \mathrm{CO}_{3}$ or $\mathrm{Na}_{2} \mathrm{CO}_{3}{ }^{5)}$ and hygroscopic components like $\mathrm{K}_{3} \mathrm{PO}_{4}$ or

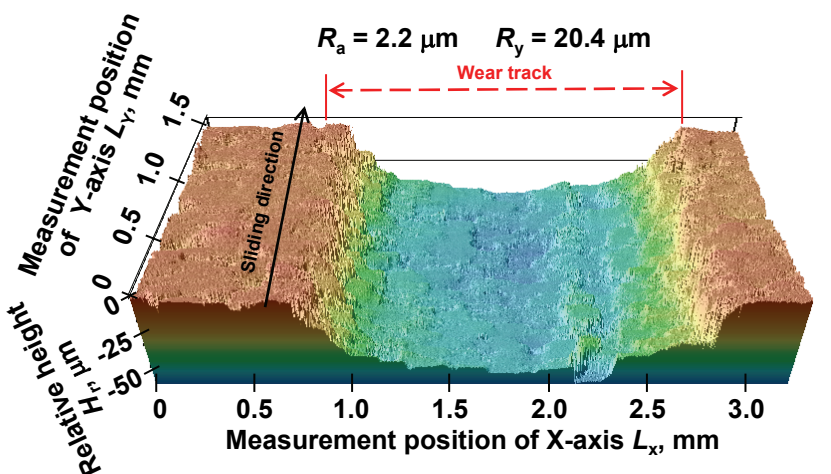

(b) $\mathrm{Cu} / \mathrm{C}$ composite disk at $1.2 \times 10^{4}$ cycles

Fig. 4 Surface profile on each composite disk after friction test 


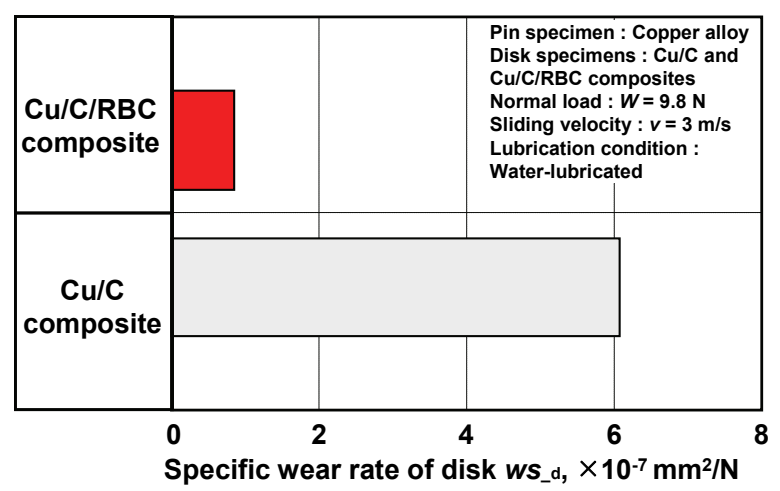

Fig. 5 Specific wear rates of each composite disk

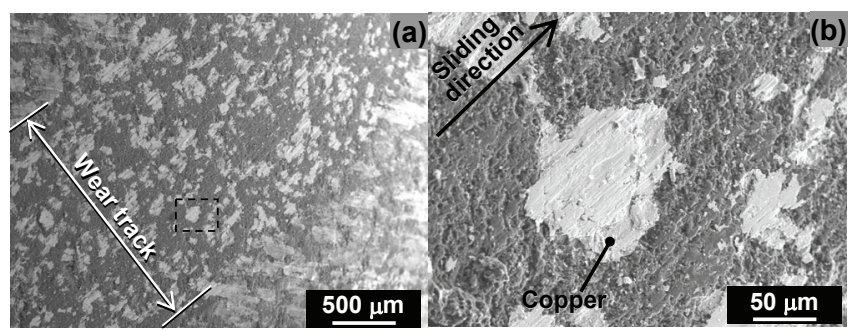

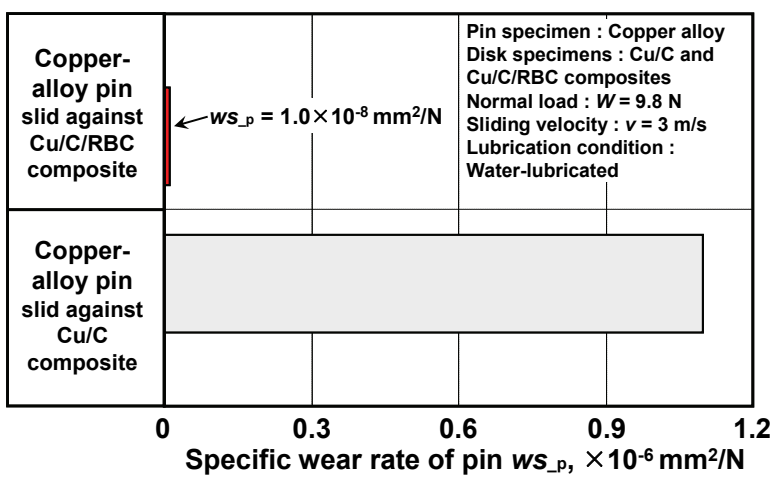

Fig. 6 Specific wear rates of copper-alloy pins slid against each composite

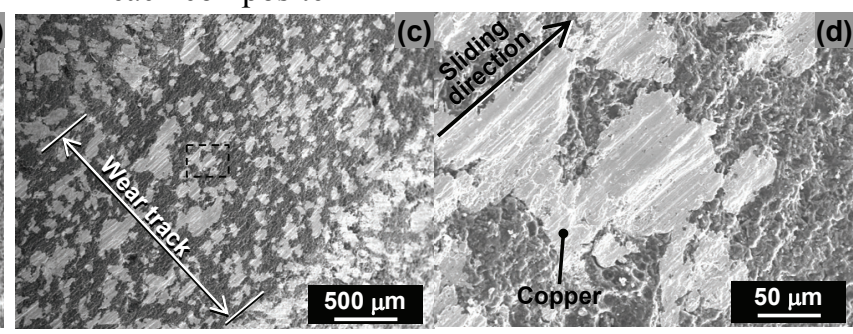

Fig. 7 SEM images of typical appearances of worn surfaces on each composite: (a) $\mathrm{Cu} / \mathrm{C} / \mathrm{RBC}$ composite; (b) enlargement of rectangular area in (a); (c) $\mathrm{Cu} / \mathrm{C}$ composite; (d) enlargement of rectangular area in (c)

$\mathrm{Na}_{3} \mathrm{PO}_{4}{ }^{5)}$ in the $\mathrm{RB}$ ceramics. Thus, the $\mathrm{RB}$ ceramics have a large hygroscopic expansion and a large reduction of mechanical strength under wet or aquatic conditions $^{6)}$. These were considered to reduce the wear resistance of the $\mathrm{Cu} / \mathrm{C} / \mathrm{RBC}$ composite under water-lubricated conditions.

In this study, the $\mathrm{Cu} / \mathrm{C} / \mathrm{RBC}$ composite has superior friction and wear properties under wet conditions without electric current. The wear-resistance of the $\mathrm{Cu} / \mathrm{C} / \mathrm{RBC}$ composite under dry conditions with arc-discharge was equivalent to the $\mathrm{Cu} / \mathrm{C}$ composite ${ }^{3)}$. The arc-discharge is also a problem for the pantograph slider sliding under wet conditions with an electric current. Thus, testing under wet conditions with an electric current should be conducted in the future.

\section{Conclusions}

(1) The friction coefficient for the $\mathrm{Cu} / \mathrm{C} / \mathrm{RBC}$ composite had a low value around 0.12 under water-lubricated conditions. As compared with the $\mathrm{Cu} / \mathrm{C}$ composite, the reduction in the friction coefficient for the $\mathrm{Cu} / \mathrm{C} / \mathrm{RBC}$ composite was $70.0 \%$.

(2) The specific wear rate of the $\mathrm{Cu} / \mathrm{C} / \mathrm{RBC}$ composite and that of the copper-alloy pin which slid against the $\mathrm{Cu} / \mathrm{C} / \mathrm{RBC}$ composite were $8.5 \times$ $10^{-8}$ and $1.0 \times 10^{-8} \mathrm{~mm}^{2} / \mathrm{N}$, respectively. The $\mathrm{Cu} / \mathrm{C} / \mathrm{RBC}$ composite showed $86.1 \%$ and $99.1 \%$ reduction in the specific wear rates of the composite disk and the copper-alloy pin, respectively, compared with the $\mathrm{Cu} / \mathrm{C}$ composite under water-lubricated conditions.

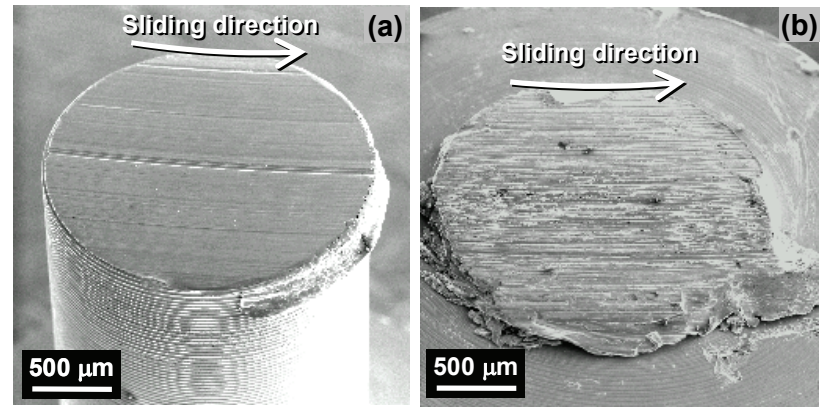

Fig. 8 SEM images of worn surfaces of copper-alloy pin: (a) sliding against $\mathrm{Cu} / \mathrm{C} / \mathrm{RBC}$ composite; (b) sliding against $\mathrm{Cu} / \mathrm{C}$ composite

\section{References}

[1] Kubo, S., Tsuchiya, H. and Teraoka, T., "Technical Trend of Metalized Carbon Contact Strips," IEICE Technical Report. EMD, 105, 359, 2005, 19-24.

[2] Shibata, K., Yamaguchi, T., Mishima, J. and Hokkirigawa, K., "Friction and Wear Properties of Copper/Carbon/RB Ceramics Composite Materials under Dry Condition," Tribology Online, 3, 4, 2008, 222-227.

[3] Shibata, K., Yamaguchi, T., Yao, Y., Yokoyama, N., Mishima, J. and Hokkirigawa, K., "Friction and Wear Properties of Copper/Carbon/RB Ceramics Composite under Electrical Current," Tribology Online, 4, 4, 2009, 131-134.

[4] Hokkirigawa, K., Shikano, S. and Takahashi, T., 
"Development of Hard Porous Materials "RB Ceramics" Made of Rice Bran," Proc. $3^{\text {rd }}$ Int. Conf. on Ecomaterials, 1997, 132-135.

[5] Kubo, S., Iizuka, H., Shibata, Y. and Shikano, S., "Improvement of Wear Resistance in Porous Carbon Materials Made from Rice Bran," Proc. $5^{\text {th }}$
Int. Conf. of Material Resources, 2005, 24.

[6] Shishido, M., Kubo, S., Yoshida, K., Takahashi, T. and Iizuka, H., "Water Resistance and Mechanical Properties of Modified Porous Carbon Materials Made from Rice Hull," J. of Society of Material Science, 56, 3, 2007, 252-257. 